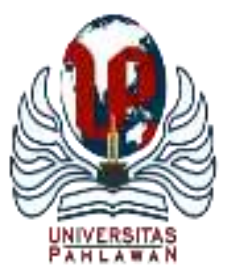

\title{
JURNALBASICEDU
}

Volume 6 Nomor 1 Tahun 2022 Halaman 1360 - 1368

Research \& Learningin Elementary Education https://jbasic.org/index.php/basicedu

\section{Kajian Gaya Belajar di Masa Pandemi}

\section{Yulia Jayanti Tanama}

STT Kharisma, Indonesia

E-mail: yuliatanama@gmail.com

\begin{abstract}
Abstrak
Penelitian ini bertujuan untuk mengkaji gaya belajar pada pembelajaran jarak jauh serta melihat apakah ada perubahan gaya belajar selama pandemi. Metode yang digunakan penelitian ini, kuantitatif deskriptif, instrumen berupa kuesioner dan teknik pengumpulan data simple random sampling. Dari 92 responden STT Kharisma, penelitian menunjukkan bahwa gaya belajar visual sebesar 53\%, audio berada 27\%, dan kinestitetik sebanyak 20\%. Berdasarkan penelitian ini, mahasiswa dapat menyesuaikan gaya belajarnya sehingga dapat menyerap informasi secara maksimal, mudah memahami materi, dan mengalami peningkatan prestasi. Pengajar juga dapat menyesuaikan gaya belajar mahasiswanya, sehingga mengajar dapat menjadi efektif dan efisien. Adanya perubahan gaya belajar sebelum dan sesudah pandemi dikarenakan perubahan proses belajar mengajar dan waktu.
\end{abstract}

Kata Kunci: gaya belajar, pandemi, pembelajaran jarak jauh

Abstract

This research is aimed to renounce the learning style by using distance learning and to keen on pandemic how learning style changing is. The method of this research uses the quantitative descriptive that is along with questionary and simple random sampling technique for taking the data. From 92 respondents at STT Kharisma, the result indicates that learning style on visual gains 53\%, audio is 27\% and kinesthetic is $20 \%$. From this research, this can be concluded that the students are able to fit their learning style into optimalize the information, gaining the knowledge on material, and getting significant differences on performances. The lecturer is also fitted the student's learning style, as a result that preferencing on teaching are more efficients. For futher, the learning style before and post pandemic needs to threatened since the changing of learning and timing.

Keywords: learning style, pandemic, distance learning

Copyright (c) 2022 Yulia Jayanti Tanama

$\triangle$ Corresponding author :

Email : yuliatanama@gmail.com

ISSN 2580-3735 (Media Cetak)

DOI : https://doi.org/10.31004/basicedu.v6i1.1689

ISSN 2580-1147 (Media Online) 


\section{PENDAHULUAN}

Pendidikan merupakan salah satu bagian yang terkena dampak dari pandemi. Sejak dilanda pandemi Virus Corona, pembelajaran berubah total. Pembelajaran tidak bisa lagi dilakukan secara tatap muka di kampus tetapi dilakukan di rumah berdasarkan Surat Edaran Menteri Pendidikan dan Kebudayaan Nomor 2 Tahun 2020 dan Nomor 3 Tahun 2020 (Kemendikbud, 2020). Kebijakan ini dilakukan untuk mengurangi penyebaran Covid-19 yang bisa menyerang siapa saja.

Dampak dari pandemi, dosen dan mahasiswa tidak bisa berinteraksi tatap muka secara langsung tetapi terpisah secara fisik. Pembelajaran jarak jauh diberlakukan untuk mengatasi batasan jarak, tempat, dan waktu dalam melaksanakan proses pembelajaran. Keunggulan pembelajaran jarak jauh dikemukan oleh (Prawiyogi et al., 2020) terjadinya distribusi pendidikan pendidikan ke seluruh penjuru Indonesia dengan daya tampung yang tidak terbatas, tidak terbatas oleh waktu, pembelajar dapat memilih bahan ajar sesuai dengan keinginan dan kebutuhan masing-masing, lama waktu belajar tergantung kemampuan pembelajar, dan pembelajaran jarak jauh dapat dilaksanakan secara interaktif. Selama masa pandemi pembelajaran jarak jauh merupakan pembelajaran pilihan yang tepat untuk mengatasi penyebaran Covid-19 (Hutami, 2021) (Kamza et al., 2021b). Keterbatasan tidak adanya tatap muka dalam pembelajaran jauh mesti dilengkapi dengan pemakaian media yang dapat terjadinya interaksi pengajar dan pembelajar. Perkuliahan dilakukan melalui aplikasi yang mendukung proses perkuliahan, mengerjakan tugas, dan mengungkapkan aktivitas perkuliahan (Harahap et al., 2020). Dibandingkan sebelum masa pandemi, pengajaran jarak jauh membutuhkan kebiasaan baru yang dilakukan dengan mendadak sangatlah tidak mudah sehingga timbul permasalahan-permasalahan.

Ada beberapa kendala yang muncul selama pembelajaran jarak jauh. Berdasarkan penelitian (Dewantara \& Nurgiansah, 2020) permasalahan dalam pembelajaran daring yaitu lemahnya sumber daya manusia, infrastuktur belum memadai, tidak semua mata kuliah bisa diajarkan secara online. Berdasarkan penelitian mahasiswa mengalami permasalahan seperti koneksi internet yang jelek, tugas banyak diselesaikan dengan waktu yang sedikit, dan adaptasi dengan situasi belajar yang berbeda (Harahap et al., 2020). Kendala yang yang ditemukan juga seperti penggunaan media internet, koneksi jaringan, dan server down dan error (W. Sari et al., n.d.). Begitu pula dengan mahasiswa STT Kharisma tersebar di berbagai pelosok di Indonesia mereka mengalami kendala yang sama. Keterbatasan sinyal seringkali menghambat proses pembelajaran juga dalam mengerjakan tugas-tugas. Selain itu, mahasiswa tidak semua memiliki perangkat yang memadai untuk pembelajaran secara daring sehingga mahasiswa tidak dapat perkuliahan maksimal.

Adanya keterbatasan yang dialami mahasiswa, dosen dituntut berpikir keras dalam menyampaikan kuliah agar materi yang disampaikan dapat dimengerti oleh mahasiswa. Pembelajar harus bisa mengembangkan kemampuan dalam menemukan, mengelola, dan mengevaluasi informasi dan pengetahuan dalam mencari penyelesaian pada kehidupan nyata sehingga ikut serta dalam kegiatan di masyarakat (Munir, 2012). Oleh sebab itu, dibutuhkan pembelajaran yang efektif dan efisien yang membuat mahasiswa dapat menerima informasi dan pengetahuan yang dipelajari menjadi bagian dari dirinya. Pembelajaran yang bermanfaat itu timbul dari motivasi diri sendiri bukan paksaaan. Mahasiswa yang selalu dipaksa dalam belajar menimbulkan terhambatnya kosentrasi dalam menerima materi yang diberikan dosen (Wahyuni, 2017). Dosen juga mengeluh materi yang disampaikan sulit diterima oleh mahasiswa sehingga perlu diatasi yaitu dengan mengetahui gaya belajar masing-masing mahasiswa.

Gaya belajar merupakan kemampuan belajar peserta didik dalam menyerap, mengolah, dan menyampaikan informasi (A. K. Sari, 2014). Gaya belajar juga kecenderungan siswa dalam mengolah langkah-langkah dalam belajar sesuai dengan desakan di kampus (Slameto, 2003). Gaya belajar peserta didik berlainan satu sama lain, ada 3 jenis gaya belajar yaitu visual, audio, dan kinestetik. Gaya belajar visual menurut (Simanjuntak, 2017) adalah seorang "pengamat" dalam mengingat informasi dengan menggambarkan sesuatu dalam pikirannya. Kemampuan mahasiswa yang memiliki gaya visual mampu mengingat $70-75 \%$ dari apa yang dibaca dan dilihatnya ketika pertama kali. Sedangkan gaya belajar audio 
merupakan seorang pendengar dan gaya belajar kinestetik merupakan pencoba dan pelaku secara langsung (Andri, 2013).

Ada mahasiswa yang lebih senang dosen mengajar dengan cara menuliskan di papan tulis atau membuat power point sehingga mahasiswa dapat membaca untuk bisa memahaminya. Sebagian mahasiswa lain lebih senang dosen mengajar dengan cara menyampaikan secara lisan sehingga mahasiswa dapat mendengarkan untuk bisa memahaminya. Ada juga mahasiswa yang lebih senang membentuk kelompok kecil untuk mendiskusikan pertanyaan terkait pelajaran. Contoh yang dikemukakan merupakan gambaran dari masing-masing gaya belajar visual, auditori, dan kinestetik. Oleh karena itu, dosen harus menyampaikan pembelajaran yang diminati mahasiswa yaitu sesuai dengan gaya belajarnya (Wahyuni, 2017).

Masalah yang terjadi seringkali dosen dan mahasiswa tidak menyadari pentingnya gaya belajar. Berdasarkan penelitian yang dilakukan (Pangesti, 2018) pada 650 guru dan kepala sekolah hanya 19 orang yang mengetahui tentang gaya belajar. Sedangkan penelitian yang dilakukan kepada 160 mahasiswa diperoleh hanya 3 orang mahasiswa yang mengetahui tentang gaya belajar. Gaya belajar belum diperhatikan dalam pembelajaran, dosen kebanyakan mengajar secara klasikal dan tidak memperhatikan gaya belajar dari mahasiswanya. Di mana dalam pengajaran klasikal memaksa semua siswa mempelajari bahan yang sama dengan kecepatan yang sama.

Tujuan penelitian ini, untuk menganalisis karakteristik gaya belajar mahasiswa STT Kharisma. Selanjutnya untuk memberikan masukan kepada dosen dan mahasiswa dalam proses belajar mengajar agar efektif dan efisien dalam pembelajaran daring. Peneliti juga memberikan gambaran pentingnya mahasiswa dan dosen mengetahui gaya belajar. Di samping itu, peneliti juga mengidentifikasi terjadinya perubahan gaya belajar sebelum dan setelah pandemi.

\section{METODE PENELITIAN}

Penelitian ini dilakukan di STT Kharisma menggunakan pendekatan kuantitatif dengan menggunakan metode deskriptif. Dalam penelitian ini, ada 92 responden yang berasal dari Magister Teologi, Sarjana Teologi, dan Sarjana Pendidikan Kristen antara semester 2 - 6. Teknik penelitian menggunakan pengambilan sampel acak. Kuesioner terdiri dari 30 pertanyaan yang mengidentifikasi gaya belajar pada mahasiswa yang terdiri dari visual, auditorial dan kinestetik. Para responden menggunakan Google Form untuk menjawab kuesioner.

\section{HASIL DAN PEMBAHASAN}

\section{Kajian Gaya Belajar tiap Program Studi}

Mahasiswa STT Kharisma melakukan pengisian instrumen angket gaya belajar melalui google form oleh 92 responden yang terdiri dari 16 responden program studi Magister Teologi, 52 responden program studi Sarjana Teologi, dan 24 responden program studi Sarjana Pendidikan Agama Kristen. Peneliti kemudian melakukan analisis terhadap hasil pengisian angket terhadap tiap pernyataan.

Tabel 1. Gaya belajar program studi Magister Teologi

\begin{tabular}{cccc}
\hline No & Gaya Belajar & Frekuensi & Persentase \\
\hline 1 & Visual & 10 & $62 \%$ \\
\hline 2 & Audio & 3 & $19 \%$ \\
\hline 3 & Kinestetik & 3 & $19 \%$ \\
\hline
\end{tabular}


Berdasarkan hasil kajian gaya belajar terhadap mahasiswa program studi Magister Teologi yang ditampilkan pada tabel 1 maka diperoleh gaya belajar visual $62 \%$, gaya belajar audio $19 \%$, dan gaya belajar kinestetik 19\%. Kecenderungan gaya belajar di progam studi Magister Teologi adalah gaya belajar visual.

Tabel 2. Gaya belajar program studi Sarjana Teologi

\begin{tabular}{cccc}
\hline No & Gaya Belajar & Frekuensi & Persentase \\
\hline 1 & Visual & 28 & $54 \%$ \\
\hline 2 & Audio & 16 & $31 \%$ \\
\hline 3 & Kinestetik & 8 & $15 \%$ \\
\hline
\end{tabular}

Hasil kajian gaya belajar terhadap mahasiswa program studi Sarjana Teologi diperoleh gaya belajar visual $54 \%$, gaya belajar audio $31 \%$, dan gaya belajar kinestetik $15 \%$. Dari data yang maka kecenderungan gaya belajar di program studi Sarjana Teologi adalah gaya belajar visual.

Tabel 3. Gaya belajar program studi Sarjana Pendidikan Agama Kristen

\begin{tabular}{cccc}
\hline No & Gaya Belajar & Frekuensi & Persentase \\
\hline 1 & Visual & 11 & $46 \%$ \\
\hline 2 & Audio & 6 & $25 \%$ \\
\hline 3 & Kinestetik & 7 & $29 \%$ \\
\hline
\end{tabular}

Hasil analisis kajian gaya belajar terhadap mahasiswa program studi Sarjana Pendidikan Agama Kristen maka diperoleh gaya belajar visual $46 \%$, gaya belajar audio $25 \%$, dan gaya belajar kinestetik $29 \%$. Dari data yang diperoleh maka kecenderungan gaya belajar program studi Sarjana Pendidikan Agama Kristen adalah gaya belajar visual.

\section{Kajian Gaya Belajar STT Kharisma}

Analisis kajian keseluruhan terhadap 92 mahasiswa STT Kharisma diperoleh gaya belajar visual 53\%, gaya belajar audio $27 \%$, dan gaya belajar kinestetik $20 \%$. Maka kecenderungan gaya belajar di STT Kharisma adalah gaya belajar visual.

Tabel 4. Gaya belajar di STT Kharisma

\begin{tabular}{ccccccc}
\hline No & $\begin{array}{c}\text { Gaya } \\
\text { Belajar }\end{array}$ & $\begin{array}{c}\text { Frekuensi } \\
\text { prodi } \\
\text { Magister } \\
\text { Teologi }\end{array}$ & $\begin{array}{c}\text { Frekuensi } \\
\text { prodi } \\
\text { Sarjana } \\
\text { Teologi }\end{array}$ & $\begin{array}{c}\text { Frekuensi } \\
\text { prodi } \\
\text { Sarjana } \\
\text { PAK }\end{array}$ & $\begin{array}{c}\text { Total } \\
\text { frekuensi }\end{array}$ & Persentase \\
\hline 1 & Visual & 10 & 28 & 11 & 49 & $53 \%$ \\
\hline 2 & Audio & 3 & 16 & 6 & 25 & $27 \%$ \\
\hline 3 & Kinestetik & 3 & 8 & 7 & 18 & $20 \%$ \\
\hline
\end{tabular}

\section{Belajar dan Mengajar bagi Mahasiswa Tipe Gaya Belajar Visual}

Mahasiswa yang bergaya belajar visual lebih maksimal jika menggunakan mata untuk melihat bagaimana melakukan sesuatu. Gaya belajar visual belajar dengan melihat dan mencermati. (DePorter, Bobbi, 2014) mengatakan ciri mahasiswa yang memiliki gaya belajar visual adalah menjaga penampilan, teratur, memperhatikan segala sesuatu, mengingat dengan gambar, tidak terganggung oleh keributan, lebih suka membaca daripada dibacakan, serta memerlukan gambaran dan tujuan secara lengkap. Mereka mengalami kesulitan dalam tuntutan akademis seperti memperhatikan pelajaran tanpa alat bantu visual dan merasa dibatasi kreativitasnya oleh kertas putih, tinta biru atau tinta hitam standar (Tobias, 2013).

Mahasiswa dengan gaya belajar visual dapat memaksimalkan belajar (Pangesti, 2018), seperti: belajar menggunakan peta, garis waktu, dan gambar, dan juga dapat memberi warna atau kode dengan menggaris 
bawahi kata-kata kunci. Sedangkan menurut (A. K. Sari, 2014) memvisualkan informasi yang diterima dengan membuat catatan yang berbentuk diagram, simbol, atau gambar, serta membuat peta pikiran atau peta konsep untuk membantu dalam menampilkan gambaran keseluruhan dari konsep. Sedangkan dalam pembelajaran jarak jauh ada beberapa hal yang dapat dilakukan dosen untuk memaksimalkan pembelajaran yaitu sebagai berikut: pertama, dosen membuat media pembelajaran dengan menggunakan diagram, kode warna, dan video. Kedua, memperhatikan apa yang menjadi kegemaran mahasiswa dengan gaya belajar visual yaitu visualisasi berupa garis besar, garis waktu, gambar statis, gambar bergerak, dan data visual lainnya. Selanjutnya, membuat power point yang menarik dilengkapi dengan gambar dan berwarna. Lalu, menghindari tes yang menggunakan pendengaran dan respons yang luas. Terakhir, memberi masukan kepada mahasiswa untuk memfokuskan imajinasi yang sedang mereka dengarkan.

\section{Belajar dan Mengajar bagi Mahasiswa Tipe Gaya Belajar Auditori}

Mahasiswa dengan gaya belajar auditori akan memiliki pemahaman ketika mendengar. Gaya belajar auditori dengan mendengar dan menyimak secara insentif. Ciri mahasiswa dengan gaya belajar auditori menurut (DePorter, Bobbi, 2014) yaitu berbicara dengan pola berirama, mudah terganggu oleh keributan, belajar dengan cara mendengarkan, membaca dengan bersuara atau menggerakkan bibir, dan berdiskusi secara internal dan ekternal. Kesulitan yang dihadapi oleh gaya belajar auditori adalah tidak dapat berbicara di dalam kelas, membaca tanpa suara, dan keceplosan tanpa mengangkat tangan (Tobias, 2013). Langkah yang dapat diambil untuk memaksimalkan belajar untuk mahasiswa dengan gaya belajar auditori menurut (Pangesti, 2018) sebagai berikut: Mahasiswa mendengarkan podcast atau rekaman dari dosen yang mengajar, membahas atau mengulang materi dengan menyuarakannya, membaca buku catatan dengan bersuara kemudian merekamnya, dan belajar berkelompok dengan cara berdiskusi. Sedangkan yang dapat dilakukan dosen untuk memaksimalkan belajar mahasiswa dilakukan dengan cara: Dosen menjelaskan dengan cara yang berbeda jika mahasiswa mengajukan pertanyaan yang mengharapkan lebih banyak penjelasan, memberikan penugasan seperti wawancara, laporan lisan, parafrase konten, memberi kesempatan untuk menunjukkan hasil belajar dengan presentasi lisan seperti ujian lisan atau menggunakan alat speech-to-text tools, memberi kesempatan mahasiswa untuk menyampaikan pendapatnya. Sedangkan menurut (A. K. Sari, 2014), dosen menyampaikan penjelasan berulang-ulang serta meminta mahasiswa menyebutkan kembali apa yang sedang dipelajari, dalam menyampaikan materi menggunakan variasi vokal, dan menggunakan metode tanya jawab, kerja kelompok, dan teknik mnemonics.

\section{Belajar dan Mengajar bagi Mahasiswa Tipe Gaya Belajar Kinestetik}

Mahasiswa yang memiliki gaya belajar kinestetik memiliki gerakan, koordinasi, irama, tanggapan emosional dan ketenangan fisik dominan. Ciri mahasiswa dengan gaya belajar kinestetik (DePorter, Bobbi, 2014) adalah belajar dengan melakukan, sering menyentuh orang, bergerak saat berinteraksi dengan orang lain, membaca dengan menunjuk tulisan, tidak dapat duduk dalam waktu yang lama, serta mengingat sambil berjalan dan melihat. Dalam pembelajaran daring, mahasiswa yang memiliki gaya belajar kinestetik mengalami kesulitan fokus. Mereka memasukkan sebanyak mungkin tindakan ke dalam perkataan dan menggerakan tubuh untuk menggambarkan apa yang dikatakan misalnya menggunakan bahasa isyarat atau gerakan tangan (Tobias, 2013). Pada pembelajaran daring, tindakan dan gerakan mereka tidak terakomodir sehingga mereka lebih cepat jenuh. Kesulitan yang dialami adalah duduk diam, melakukan hal yang sama lebih dari 10 menit dalam satu waktu, menatap ketika sedang berbicara (Tobias, 2013).

Menurut (Pangesti, 2018) berpendapat bahwa ada beberapa cara dalam memaksimalkan mahasiswa yang memiliki gaya belajar kinestetik, seperti: mahasiswa akan sering melakukan jeda istirahat, melakukan kegiatan eksperimen secara langsung, diterapkan secara berkelompok, dan selalu belajar dengan meremasremas benda (bola) atau sambil menggerakkan anggota tubuhnya. Sehingga yang dapat dilakukan dosen untuk memaksimalkan belajar mahasiswa gaya belajar kinestetik dilakukan dengan cara sebagai berikut: Dosen 
melakukan pembelajaran dengan membuat model materi ajar, bereksperimen langsung, menghindari tes yang memerlukan tulisan yang banyak seperti esai, membuat ujian dalam bentuk pemecahan masalah, tidak melarang mahasiswa untuk menggambar atau bergerak sambil mendengarkan penjelasan, memberikan tugas berupa proyek terapan(A. K. Sari, 2014), dan membuat simulasi konsep sehingga mahasiswa mengalaminya (A. K. Sari, 2014).

\section{Pentingnya Mengetahui Gaya Belajar}

Setiap manusia mempunyai kelebihan dan kekurangan yang membedakan manusia satu dengan manusia lainnya. Jika kelebihan diperhatikan dan dikembangkan dengan maksimal maka manusia akan berprestasi atau belajar dengan optimal. Sedangkan jika kekurangan dapat diketahui untuk diperbaiki maka akan mengembangkan diri secara optimal. Berpatokan dari perbedaan manusia maka dengan mengajar dengan bahan yang sama, metode yang sama, serta cara penilaian yang sama kepada semua siswa akan menghasilkan yang sama adalah tidak tepat. Siswa memiliki kecerdasan, kepribadian, abilitas, emosional, ing atan, dan minat yang berbeda. Selain itu, siswa juga berbeda bentuk, ukuran, kekuatan, dan daya tahan tubuh. Perbedaan juga terjadi pada gaya belajar ada yang menonjol gaya belajar visual, audio, atau kinestetik. Oleh karena itu, pembelajaran harus memperhatikan perbedaan individu sehingga lebih meningkatkan kemampuan dan potensi yang dimilikinya (Ghufron \& Risnawita, 2012).

Karakteristik gaya belajar perlu diketahui oleh mahasiswa dan dosen menurut (Pangesti, 2018) bagi mahasiswa dapat menyerap informasi secara maksimum sedangkan bagi dosen untuk menyediakan pembelajaran yang disenangi oleh mahasiswa. Dengan mengetahui gaya belajar, maka dosen dan mahasiswa akan mengerti strategi apa yang perlu dilakukan dalam belajar atau mengajar. Kemampuan mahasiswa dalam mengetahui gaya belajar yang menonjol pada diri sendiri dan orang lain akan meningkatkan afektifitas dalam belajar (Ghufron \& Risnawita, 2012). Gaya belajar yang sesuai dengan kemauan mahasiswa menjadikan mahasiswa lebih mudah memahami materi yang diajarkan dan meningkatkan prestasi (Wibowo, 2016). Diperkuat dengan penelitian yang dilakukan (Bire Arylien Ludji, Geradus Uda, 2014) terdapat pengaruh signifikan gaya visual, auditorial, dan kinestetik terhadap prestasi belajar. Penelitian yang dilakukan (Wibowo, 2016) yaitu pemanfaatan gaya belajar dapat meningkat keaktifan berdasarkan perhatian, kerjasama dan hubungan sosial, mengemukakan pendapat atau ide, pemecahan masalah, dan displin sehingga menjadi dasar pentingnya mengetahui gaya belajar.

Pentingnya pemahaman tentang gaya belajar juga diungkapkan oleh (Karim et al., 2019) baik itu oleh mahasiswa maupun dosen. Mahasiswa akan terbantu dalam penggunaan strategi pembelajaran yang tepat yang menjadikan mereka pembelajar seumur hidup dan memiliki kemandirian sehingga dapat memaksimalkan potensi yang ada pada dirinya. Sedangkan dosen dapat menggabungkan gaya belajar dalam metode belajar dan mengajar untuk memaksimalkan pembelajaran. Selain itu, usaha yang dapat dilakukan dosen untuk melengkapi perbedaan gaya belajar bisa dilakukan dengan cara menggunakan program, metode, pengelolaan kelas yang lebih variatif. Sehingga tidak hanya menciptakan lingkungan belajar yang efisien tetapi akan memotivasi mahasiswa dalam memperoleh prestasi.

Pentingnya setiap siswa mengetahui gaya belajar masing-masing menurut (Honey \& Mumford, 2006) sebagai berikut: meningkatkan kesadaran kita dalam memilih aktivitas belajar yang sesuai atau tidak sesuai dengan gaya belajar yang menonjol dalam diri kita, membantu menentukan pilihan aktivitas belajar yang tepat dan terhindar dari pengalaman yang tidak tepat, mahasiswa yang memiliki kemampuan belajar kurang efektif dapat melakukan improvisasi, dan membantu mahasiswa dalam merencanakan tujuan dari belajar dan melihat keberhasilannya.

Dosen juga perlu memahami gaya belajar yang dimiliki mahasiswa agar metode pembelajaran dapat disesuaikan. Sedangkan alasan (Honey \& Mumford, 2006) pentingnya dosen mengetahui gaya belajar mahasiswanya sebagai berikut: pertama, membuat proses belajar mengajar dialogis. Perubahan paragdima bukan tugas pengajar yang mengisi mahasiswa dengan pengetahuan tetapi belajar dapat diibaratkan dengan 
"dialog" yang lebih interaktif, kooperatif, dan memiliki relasi. Maka dosen sudah seyogyanya tidak menggunakan metode ceramah saja tetapi mengembangkan metode pembelajaran sehingga pembelajaran di kelas menjadi lebih aktif adanya keterlibatan mahasiswa dalam tanya jawab. Kedua, memahami pelajar adalah individu yang berbeda. Perbedaan terjadi dalam berbagai hal seperti jenis kelamin, usia, bangsa, negara, budaya, dll. Keragamanan ini dapat mempengaruhi kelas termasuk gaya belajar mahasiswa. Ketiga, berkomunikasi melalui pesan. Dosen perlu mengetahui kecenderungan gaya belajar mahasiswanya agar dalam mengajar dapat menyesuaikan. Selain itu, dosen juga dapat mengaitkan dengan materi yang akan diberikan dan memahami berapa banyak materi yang sesuai dengan pendekatan pengajaran yang telah ditetapkan. Misalnya dalam 50 menit pembelajaran di kelas, para mahasiswa kira-kira bisa mempertahankan 70\% dari apa yang disampaikan pada 10 menit pertama dan hanya $20 \%$ pada 10 menit terakhir. Jika dosen menyampaikan materi ingin diterima benar maka harus mengkolaborasi berbagai pendekatan sehingga materi tersampaikan dengan baik terutama sesuai dengan gaya belajar yang dimiliki mahasiswa. Empat, membuat proses pengajaran lebih banyak memberi penghargaan. Bila kita tidak perlu memperhatikan refleksi proses pengajaran yang sudah dilakukan, kita mungkin akan mengajar yang terbaik menurut kita, tetapi dosen perlu menyesuaikan dengan keanekaragaman mahasiswa yang ada. Institusi mempunyai peran penting dalam memberikan inovasi-inovasi dengan mempertimbangkan gaya belajar yang mahasiswa miliki.

Gaya belajar menggambarkan bentuk pembelajaran yang dimiliki setiap individu secara unik dalam proses pembelajaran dalam menyeleksi, menerima, menyerap, menyimpan, mengelolah, dan memproses informasi. Proses pembelajaran sebelum pandemi dan setelah pandemi tentunya terjadi perubahan-perubahan yang besar. Berdasarkan ini, peneliti ingin mengetahui apakah adanya perubahan gaya belajar sebelum dan sesudah pandemi.

Berdasarkan penelitian yang telah dilakukan Papilaya dan Huliselan pada pembelajaran sebelum pandemi untuk menganalisis gaya belajar ditemukan dari 39 mahasiswa diperoleh 6 mahasiswa minat gaya belajar visual, 20 mahasiswa memiliki minat gaya belajar auditorial, 1 mahasiswa memiliki minat gaya belajar kinestetik, dan 12 mahasiswa memiliki minat haya belajar campuran yaitu gaya belajar visual dan gaya belajar auditorial (Papilaya \& Huliselan, 2016). Kecenderungan gaya belajar mahasiswa Program Studi Bimbingan dan Konseling FKIP Unpatti adalah auditorial. Penelitian lainnya oleh (Wahyuni, 2017) pada mahasiswa program studi Pendidikan Matematika untuk angkatan 2012 didominasi oleh gaya belajar audiotorial 50\%, angkatan 2013 didominasi oleh gaya belajar auditorial 45\%, angkatan 2014 didominasi auditorial 50\%, dan angkatan 2015 didominasi oleh gaya belajar visual 50\%. Penelitian lain pada mahasiswa kedokteran yang dilakukan (Karim et al., 2019) kecenderungan gaya belajar visual dan kinestetik.

Hasil analisis pada mahasiswa dalam pembelajaran setelah pandemi yaitu pembelajaran daring yang dilakukan peneliti di STT Kharisma dari tiga prodi semua kecenderungan gaya belajar visual. Sedangkan penelitian yang dilakukan sebelumnya, terdapat variasi kecenderungan gaya belajar ada yang auditori dan kinestetik. Apakah pembelajaran daring mengakibatkan terjadi perubahan gaya belajar? Menurut penelitian (Mitchell, James, 2015) terhadap mahasiswa keperawatan dan kebidanan terjadi perubahan 50\% pada gaya belajar yang diukur dalam jangka waktu 6 bulan. Penelitian pada mahasiswa keperawatan yang dilakukan (Aldosari et al., 2018) juga menghasilkan hal yang sama.

Perubahan gaya belajar bisa karena adanya perbedaan proses belajar mengajar yang diterapkan pada masa sebelum pandemi dan setelah pandemi. Selain itu perubahan gaya belajar dapat dipengaruhi oleh karakteristik institusi dalam melaksanakan proses belajar mengajar (Akbar Surya, Darungan Tezar Samekto, 2021). Perubahan gaya belajar juga bisa terjadi berdasarkan waktu menurut (Aldosari et al., 2018) dan (Mitchell, James, 2015).

Penelitian yang dilakukan (Evy, 2021) menyatakan bahwa pembelajaran daring membawa perubahan gaya belajar siswa. Dalam pembelajaran daring, gaya belajar visual paling banyak dilakukan oleh mahasiswa. Menurut (Kamza et al., 2021a) juga kebanyakan peserta didik berprestasi pada pembelajaran online adalah gaya belajar visual. Hal ini sesuai dengan hasil kajian peneliti pada mahasiswa STT Kharisma ketiga prodinya 
cenderung memiliki gaya belajar visual. Perubahan itu ada yang positif seperti siswa menjadi lebih aktif dan kreatif dan perubahan negatif seperti kemorosotan motivasi belajar. Kunci utama perubahan gaya belajar ada pada pendidik dimana pendidik dituntut untuk lebih kreatif dan inovatif dalam menumbuhkan minat dan motivasi belajar. Faktor penting yang menjadi perhatian agar pembelajaran daring berlangsung dengan baik yaitu perhatian, kepercayaan diri pendidik, pengalaman, mudah menggunakna peralatan, kreatif menggunakan alat, dan menjalin interaksi dengan peserta didik (Prawiyogi et al., 2020).

\section{KESIMPULAN}

Berdasarkan kajian gaya belajar di STT Kharisma maka dapat diambil kesimpulan dari 92 responden diperoleh gaya belajar visual $62 \%$ pada prodi Magister Teologi, gaya belajar visual 54\% prodi Sarjana Teologi, dan gaya belajar visual $46 \%$ prodi Sarjana Pendidikan Agama Kristen. Jadi berdasarkan kajian analisis gaya belajar di STT Kharisma diperoleh kecenderungan gaya belajar visual 53\%. Mahasiswa dalam belajar perlu menyesuaikan dengan gaya belajar sehingga mahasiswa dapat menyerap informasi secara maksimum, meningkatkan afektifitas dalam belajar, mudah mamahami materi, meningkatkan prestasi, meningkat keaktifan berdasarkan kerjasama dan hubungan sosial, mengemukakan pendapat atau ide, pemecahan masalah, dan displin. Dosen dalam mengajar harus memperhatikan gaya belajar mahasiswanya dalam menyediakan pembelajaran yang disenangi mahasiswa, strategi yang perlu dilakukan dalam mengajar, memilih metode mengajar yang sesuai, cara menggunakan program, pengelolaan kelas yang lebih variatif sehingga mengajar menjadi lebih efektif dan efisien. Berdasarkan penelitian, adanya perubahan gaya belajar sebelum dan sesudah pandemi dikarenakan perubahan proses belajar mengajar dan waktu.

\section{DAFTAR PUSTAKA}

Akbar Surya, Darungan Tezar Samekto, T. H. (2021). Investigasi Perubahan Gaya Belajar Mahasiswa Fakultas Kedokteran : Penelitian Longitudinal. 5(2), 214-223.

Aldosari, M. A., Aljabaa, A. H., Al-Sehaibany, F. S., \& Albarakati, S. F. (2018). Learning Style Preferences Of Dental Students At A Single Institution In Riyadh, Saudi Arabia, Evaluated Using The Vark Questionnaire. Advances In Medical Education And Practice, 9, 179-186. Https://Doi.Org/10.2147/Amep.S157686

Andri, P. (2013). Pahami Gaya Belajar Anak. Jakarta: Elex Media Komputindo.

Bire Arylien Ludji, Geradus Uda, B. J. (2014). Pengaruh Gaya Belajar Visual, Auditorial, Dan Kinestetik Terhadap Prestasi Belajar Siswa. Jurnal Kependidikan: Penelitian Inovasi Pembelajaran, 44(2), 128164. Https://Doi.Org/10.21831/Jk.V44i2.5307

Deporter, Bobbi, \& S. S.-N. (2014). Quantum Teaching. Bandung: Pt. Mizan Pustaka.

Dewantara, J. A., \& Nurgiansah, T. H. (2020). Efektivitas Pembelajaran Daring Di Masa Pandemi Covid 19 Bagi Mahasiswa Universitas Pgri Yogyakarta. Jurnal Basicedu, 5(1), 367-375. Https://Doi.Org/10.31004/Basicedu.V5i1.669

Evy, A. (2021). Perubahan Gaya Belajar Di Masa Pandemi Covid-19. Jurnal Cendekia, 7(1), 6.

Ghufron, N., \& Risnawita, R. (2012). Gaya Belajar Kajian Teoritik. Yogyakarta: Pustaka Pelajar.

Harahap, A. C. P., Harahap, D. P., \& Harahap, S. R. (2020). Analisis Tingkat Stres Akademik Pada Mahasiswa Selama Pembelajaran Jarak Jauh Dimasa Covid-19. Biblio Couns : Jurnal Kajian Konseling Dan Pendidikan, 3(1), 10-14. Https://Doi.Org/10.30596/Bibliocouns.V3i1.4804

Honey, P., \& Mumford, A. (2006). The Learning Styles. Linden Avenue Maidenhead Berks: Peter Honey Publications

Hutami, E. R. (2021). Kendala Pembelajaran Jarak Jauh Pada Masa Pandemi Bagi Siswa Sd, Guru, Dan 
1368 Kajian Gaya Belajar di Masa Pandemi - Yulia Jayanti Tanama

DOI: https://doi.org/10.31004/basicedu.v6i1.1689

Orangtua. Jurnal Ilmiah Wuny, 3(1), 51-61. Https://Doi.Org/10.21831/Jwuny.V3i1.40706

Kamza, M., Husaini, \& Ayu, I. L. (2021a). Analisis Gaya Belajar Peserta Didik Berprestasi Selama Pandemi Covid-19 Dalam Pembelajaran Tematik Di Sekolah Dasar. Jurnal Basicedu, 5(5), 4120-4126. Https://Doi.Org/10.31004/Basicedu.V5i5.1347

Kamza, M., Husaini, \& Ayu, I. L. (2021b). Pemanfaatan Aplikasi Google Classroom Dalam Meningkatkan Efektivitas Belajar Mahasiswa Berbasis Daring Di Masa Pandemik Covid-19. Jurnal Basicedu, 5(5), 4120-4126. Https://Doi.Org/10.31004/Basicedu.V5i5.1347

Karim, M. R., Asaduzzaman, A., Talukder, M. H. K., Alam, K. K., Haque, F., \& Khan, S. J. (2019). Learning Style Preferences Among Undergraduate Medical Students: An Experience From Different Medical Colleges Of Bangladesh. Bangladesh Journal Of Medical Education, 10(2), 26-30. Https://Doi.Org/10.3329/Bjme.V10i2.44640

Kemendikbud. (2020). Kemendikbud. Surat Edaran Nomor 3 Tahun 2020 Tentang Pencegahan Corona Virus Disease (Covid-19) Pada Satuan Pendidikan, 33, $1-5$. Https://Www.Kemdikbud.Go.Id/Main/Blog/2020/03/Surat-Edaran-Pencegahan-Covid19-Pada-SatuanPendidikan

Mitchell, James, \& D. (2015). How Learning Styles And Preferences Of First-Year Nursing And Midwifery Students Change. Australian Journal Of Education, 59(2), 158-168. Https://Doi.Org/10.1177/00049441155879\%0a17

Munir. (2012). Pembelajaran Jarak Jauh Berbasis Teknologi Informasi Dan Komunikasi. Bandung: Alfabeta.

Pangesti, W. (2018). Seri Manual Gls Pentingnya Memahami Gaya Belajar, Jakarta: Kementerian Pendidikan Dan Kebudayaan.

Papilaya, J. O., \& Huliselan, N. (2016). Identifikasi Gaya Belajar Mahasiswa. Jurnal Psikologi Undip, 15(1), 56. Https://Doi.Org/10.14710/Jpu.15.1.56-63

Prawiyogi, A. G., Purwanugraha, A., Fakhry, G., \& Firmansyah, M. (2020). Efektifitas Pembelajaran Jarak Jauh Terhadap Pembelajaran Siswa Di Sdit Cendekia Purwakarta. Jurnal Pendidikan Dasar, 11(01), 94 101.

Sari, A. K. (2014). Analisis Karakteristik Gaya Belajar Vak(Visual, Auditorial, Kinestetik)Mahasiswa Pendidikan Informatika Angkatan 2014. Edutic - Scientific Journal Of Informatics Education, 1(1), 112. Https://Doi.Org/10.21107/Edutic.V1i1.395

Sari, W., Rifki, A. M., \& Karmila, M. (2020.). Pembelajarn Jarak Jauh Pada Masa Darurat Covid 19. Jurnal Mappesona, 3(2).

Simanjuntak, J. (2017). Ilmu Belajar Dan Didaktika Pendidikan Kristen. Yogyakarta: Andi.

Slameto. (2003). Belajar Dan Faktor-Faktor Yang Mempengaruhinya. Jakarta: Rineka Cipta.

Tobias, C. U. (2013). Setiap Anak Bisa Berhasil: Memaksimalkan Gaya Belajar Anak Anda. Bandung: Pionir Jaya.

Wahyuni, Y. (2017). Identifikasi Gaya Belajar ( Visual, Auditorial, Universitas Bung Hatta. Jppm, 10(2), $128-132$.

Wibowo, N. (2016). Upaya Peningkatan Keaktifan Siswa Melalui Pembelajaran Berdasarkan Gaya Belajar Di Smk Negeri 1 Saptosari. Elinvo (Electronics, Informatics, And Vocational Education), 1(2), 128-139. Https://Doi.Org/10.21831/Elinvo.V1i2.10621 